\title{
Wage Discrimination against Women in Baltic Countries
}

\author{
Veronika HEDIJA-Petr MUSIL*
}

\begin{abstract}
The paper is devoted on the wage differences between men and women in Baltic countries. It aims to estimate the unexplained gender pay gap cleaned at least partially by effect of intra household specialization on wage. To estimate the unexplained gender pay gap, we use European Union Statistics on Income and Living Conditions (EU-SILC) data and apply the Oaxaca-Blinder decomposition accompanied by matching procedure. The results show that to take intrahousehold specialization into account led to a decrease in the unexplained gender wage differences however wage differences between men and women persists. The unexplained gender pay gap, which could be due to wage discrimination against women reaches approximately 11 percent in Latvia and Lithuania. It is significantly higher in Estonia where it amounts about 21 percent to disadvantage of women.
\end{abstract}

Keywords: gender pay gap, wage differences, wage discrimination, Oaxaca-Blinder decomposition, Baltic countries

JEL Classification: J31, J71, M50

DOI: https://doi.org/10.31577/ekoncas.2020.07.03

\section{Introduction}

According to Eurostat data, wage differential between men and women reached 25.3 percent in 2016 in Estonia and was one of the highest in the European Union. On the other hand, the gender pay gap in the other two Baltic states Lithuania and Latvia were incomparably lower, it amounted 14.4 percent in Lithuania and 17 percent in Latvia and these were around the European Union average.

\footnotetext{
* Veronika HEDIJA (ORCID 0000-0002-5353-1505), corresponding author - Petr MUSIL (ORCID 0000-0002-8164-2181), College of Polytechnics Jihlava, Department of Economic Studies, Tolstého 16, 58601 Jihlava, Czech Republic; e-mail: veronika.hedija@vspj.cz; petr.musil@vspj.cz
} 
However, the above reported wage differences are unadjusted. The part of gender pay gap (or in extreme case all wage differences) can be explained by different average characteristics of men and women in the labor market. Only the part, that could not be explained by these factors can be attributed to wage discrimination against women. Estimates of potential wage discrimination are more accurate, the more characteristics of men and women are known and reflected in the models. The traditionally included characteristics are age, tenure, education, marital status, occupation, industry, region and firm.

Intra household specialization is the factor, that is often neglected in empirical studies and that could be the factor that play an important role in explaining the wage differences between men and women. A number of empirical studies conclude that working mothers earn less than women with no children. There are more theoretical arguments for existence of family gap: different abilities and preferences of women with children, limited mobility, lower accumulated human capital and discrimination against mothers (Felfe, 2012). However, caring for the family and children may not only be the cause of a lower wage for women, it may also influence the earnings of men. The studies show that the family penalty for women ranges from 10 to 15 percent. On the other hand, marriage and a family increase the wage of men by $10-15$ percent (Waldfogel, 1998).

To cleanse the wage differences between men and women at least partially of the effect of intra-household specialization on productivity and work effort, Hedija (2014) estimated the gender pay gap using subsample of employees earning more than their partners assuming that the larger part of care for the household and children is taken up by the partner earning less. Using the European Union Statistics on Income and Living Conditions (EU-SILC) data for 19 member countries of the European Union, she concluded that the unexplained part of gender pay gap amounted approximately 10 percent working to the disadvantage of women. Here, we follow this approach.

The paper aims to estimate the unexplained gender pay gap cleaned at least partially by effect of intra household specialization on wage in Baltic countries. To achieve this, we use a subsample of employees earning more than their partners assuming that the larger part of care for the household and children is taken up by the partner earning less.

This study brings new insights into wage differences between men and women in the Baltic countries. In addition to the traditional estimate of an unexplained gender pay gap that may be the result of wage discrimination against women in the labour market, the non-standard wage gap estimate for employees earning more than their live partner is also provided. Using a relatively simple method, the paper brings a deeper view of the issue. It also allows us at least partially to 
clear the unexplained pay gap on the effect of division of labour between the men and women in the family.

The paper is organized as follows. Section 1 provides background information on wage differences between men and women. Section 2 presents the used data and applied methods. To estimate the unexplained part of the gender pay gap, the Oaxaca-Blinder decomposition and matching procedure is employed. In section 3, we apply the methods on EU-SILC data for Baltic countries and estimate the unexplained gender pay gap using the sample of employees earning more than their partner. It represents the upper limit of wage discrimination against women. The last section contains the conclusion.

\section{Literature Review}

A number of empirical studies are devoted to the wage differences between men and women and the estimation of the "discrimination" part of gender pay gap. The studies by Oaxaca (1973) and Blinder (1973) belong to the pioneering works on the field of wage discrimination against women and decomposition of gender pay gap between explained and unexplained part. These authors independently estimated the amount of discriminatory pay gap in the United States and concluded that different characteristics of men and women could account for more than half of the existing gender pay gap. The remaining part could be considered discriminatory.

A lot of authors follow these studies and apply very often Oaxaca-Blinder decomposition or its modifications to estimate the part of gender pay gap that may be the result of wage discrimination in individual countries. The papers by Weichselbaumer and Winter-Ebmer (2005) or Hedija and Musil (2010) bring the overview of selected studies and its results. The conclusions of the studies vary, depending on the country for which the decomposition is performed, the source of the data, the number of explanatory variables included and the applied method of decomposition. Nevertheless, the conclusions of these papers confirm that differences in human capital in the form of education and experience explain only a tiny fraction of the existing gender pay gap in advanced market economies. A significant part of wage differences is explained by horizontal and vertical segregation. That is, the concentration of women in less paid industries and in the positions with lower levels of authority and responsibility, and therefore less paid. In addition, a large part of the pay gap remains unexplained.

After the fall of iron curtain, the studies examining this phenomenon in postcommunist countries started to appear. For example, Adamchik and Bedi (2003) or Goraus and Tyrowicz (2014) presented the results for Poland, Filipová et al. 
(2012) or Balcar and Gottvald (2016) for the Czech Republic, Pailhe (2000) or Mysíková (2012) for all Visegrad Group countries, Rõõm and Kallaste (2004) or Anspal (2015) for Estonia. While relatively high attention is paid to this issue in some post-communist countries, it is rather at the edge of interest in others. If we focus on the Baltic countries, the issue is relatively well described for Estonia (for overview see for example Anspal, 2015). On the other hand, studies estimating the potential wage discrimination in the labor market in Lithuania and Latvia are rare (for Latvia Vilerts and Krasnopjorovs, 2016). However, conclusions are these studies are often difficult to compare due to different estimation methods and data used.

The comparable estimates of unexplained wage gap from methodical point of view for all three Baltic countries can be found in studies that provide estimates for selected European countries. These are studied by Christofides, Polycarpou and Vrachimis (2013) or Hedija (2018) for example. Christofides, Polycarpou and Vrachimis (2013) estimated the unexplained part of gender pay gap for 26 European country using 2007 data from European Union Statistics on Income and Living Conditions (EU-SILC) and Oaxaca-Ransom decomposition. The unexplained gender pay gap varied in individual Baltic states. It reached 19.8 percent in Estonia, 15.6 percent in Latvia and 17.7 percent in Lithuania. Using the Heckman-corrected Oaxaca-Ransom decomposition, the differences was deeper. Unexplained gender pay gap was 31 percent in Estonia and 17.2 in Latvia and 11.4 percent in Lithuania. Also Hedija (2018) used data from European Union Statistics on Income and Living Conditions but for the period 2010 - 2012 and applied Oaxaca-Blinder decomposition to estimate the unexplained part of the gender pay gap. According to this study the unexplained part of gender pay gap reached $17-18$ percent in Lithuania and Latvia and 30 percent in Estonia. Conclusions of these studies show that both the overall wage gap and its unexplained part are different in the individual Baltic countries and the highest are in Estonia.

Reasons for the differences found may be more. One but certainly not just one could be the omission associated with the estimation of the potentially discriminatory component of gender pay gap. For example, Anspal (2015) uses data for Estonia and confirms that the more detailed employee characteristics are used to estimate the unexplained pay gap, the lower the unexplained portion of the gender pay gap. Hedija (2014) used EU-SILC data for 19 member countries of the European Union and estimated the unexplained gender pay gap, cleansed at least partially of the effect of intra-household specialization on productivity. The inclusion of this effect has led to a significant decrease in unexplained gender pay gap by approximately 6 percentage points. Differences in unobserved characteristics of employees in the Baltic countries may, to some extent, be in the 
background of the identified differences in potential wage discrimination in these countries. The aim of this study is to provide new estimates of unexplained pay gap in the Baltic countries that can refine the data presented so far.

\section{Data and Methods}

We use data from European Union Statistics on Income and Living Conditions (EU-SILC) which contains multidimensional micro-data on income, poverty, social exclusion and living conditions. We use cross-sectional from data from EU-SILC 2016, which covers data from 32 European countries and extracted the data for three countries: Lithuania, Latvia and Estonia.

Unfortunately, EU-SILC data does not contain information on hourly gross wages. It was therefore necessary to narrow down the sample to be able calculate the hourly gross wage using the available data. We narrowed down the reference population sample to persons who: were employees during the reference period, worked all twelve months in a full-time job, had no other jobs and earned an income. We excluded the self-employed, as we are interested in wages and the potential different evaluation of male and female employees by the employer.

We use data based on the selected personal and company characteristics of the employee: age, education level (highest attained education level according to International Standard Classification of Education (ISCED, 2011)), sickness (temporary inability to work due to sickness during the income reference year), partnership (having a partner living in the same household), occupation (according to the International Standard Classification of Occupations (ISCO-08)), sector (economic activity using the Statistical Classification of Economic Activities in the European Community (NACE Rev.2)), company size (categories for number of persons working at the local unit), contract (having a work contract of limited duration), managerial position (having a formal responsibility supervising a group of other employees), gross hourly wage and gross hourly wage of the partner. The gross hourly wage is calculated as the employee's cash and non-cash incomes per year divided by the number of hours usually worked per year (including overtime). Descriptive statistics of the used dataset are shown in Table 1.

To illustrate the gender wage differences in the different group of population, we work with three samples of employees: full sample of employees (with and without partner), employees having partner (living in the same household) and employees earning more than their partner. Figure 1 shows the raw gender pay gap in Baltic countries calculated as the difference in logarithm of average female and male gross hourly wage for these three groups of employees. The difference in mean log wages of men and women can be approximately interpreted as the percentage difference in average wages of men and women. 
Table 1

Means of the Used Variables

\begin{tabular}{|c|c|c|c|c|c|c|}
\hline \multirow[t]{2}{*}{ Variable } & \multicolumn{2}{|c|}{ Estonia (EE) } & \multicolumn{2}{|c|}{ Lithuania (LT) } & \multicolumn{2}{|c|}{ Latvia (LV) } \\
\hline & men & women & men & women & men & women \\
\hline Ln hourly wage & $\begin{array}{c}1.839 \\
(0.631)\end{array}$ & $\begin{array}{c}1.604 \\
(0.541)\end{array}$ & $\begin{array}{c}1.398 \\
(0.545)\end{array}$ & $\begin{array}{c}1.305 \\
(0.535)\end{array}$ & $\begin{array}{c}1.612 \\
(0.535)\end{array}$ & $\begin{array}{c}1.472 \\
(0.513)\end{array}$ \\
\hline Age & $\begin{array}{c}43.305 \\
(12.579) \\
\end{array}$ & $\begin{array}{c}46.468 \\
(11.275)\end{array}$ & $\begin{array}{c}46.021 \\
(11.874)\end{array}$ & $\begin{array}{c}47.456 \\
(10.476)\end{array}$ & $\begin{array}{c}42.829 \\
(12.450)\end{array}$ & $\begin{array}{c}45.927 \\
(11.897) \\
\end{array}$ \\
\hline $\begin{array}{l}\text { Education }{ }^{1)} \\
\text { Less than primary, primary, lower } \\
\text { secondary } \\
\text { Upper secondary, post-secondary } \\
\text { non tertiary } \\
\text { Tertiary education } \\
\end{array}$ & $\begin{array}{l}0.175 \\
0.565 \\
0.260 \\
\end{array}$ & $\begin{array}{l}0.078 \\
0.441 \\
0.481 \\
\end{array}$ & $\begin{array}{l}0.046 \\
0.647 \\
0.306 \\
\end{array}$ & $\begin{array}{l}0.017 \\
0.526 \\
0.457 \\
\end{array}$ & $\begin{array}{l}0.111 \\
0.644 \\
0.245 \\
\end{array}$ & $\begin{array}{l}0.046 \\
0.497 \\
0.458 \\
\end{array}$ \\
\hline $\begin{array}{l}\text { Occupation (ISCO-08, } 1 \text { digit) } \\
\text { Armed forces } \\
\text { Managers } \\
\text { Professionals } \\
\text { Tech. and associate professionals } \\
\text { Clerical support workers } \\
\text { Service and sales workers } \\
\text { Skilled agricultural, forestry and fish. } \\
\text { workers } \\
\text { Craft and related trades workers } \\
\text { Plant and machine operators and } \\
\text { assemblers } \\
\text { Elementary occupations }\end{array}$ & $\begin{array}{l}0.008 \\
0.092 \\
0.109 \\
0.111 \\
0.036 \\
0.053 \\
0.015 \\
0.262 \\
0.253 \\
0.061\end{array}$ & $\begin{array}{l}0.000 \\
0.095 \\
0.247 \\
0.135 \\
0.092 \\
0.203\end{array}$ & $\begin{array}{l}0.005 \\
0.093 \\
0.147 \\
0.070 \\
0.018 \\
0.071\end{array}$ & $\begin{array}{l}0.001 \\
0.076 \\
0.352 \\
0.086 \\
0.069 \\
0.159\end{array}$ & $\begin{array}{l}0.008 \\
0.063 \\
0.127 \\
0.122 \\
0.027 \\
0.076 \\
0.022 \\
0.238 \\
0.216 \\
0.103\end{array}$ & $\begin{array}{l}0.001 \\
0.071 \\
0.250 \\
0.191 \\
0.076 \\
0.222\end{array}$ \\
\hline Sickness ${ }^{1)}$ & 0.219 & 0.288 & 0.327 & 0.368 & 0.169 & 0.236 \\
\hline Partnership (having partner) ${ }^{1)}$ & 0.784 & 0.714 & 0.767 & 0.659 & 0.685 & 0.559 \\
\hline $\begin{array}{l}\text { Sector (NACE Rev. 2) }{ }^{1)} \\
\text { Agriculture, forestry and fishing (A) } \\
\text { Mining, manufacturing, electricity, } \\
\text { water...(B - E) } \\
\text { Construction (F) } \\
\text { Wholesale and retail trade... (G) } \\
\text { Transportation and storage (H) } \\
\text { Accommodation and food } \\
\text { service...(I) } \\
\text { Information and communication (J) } \\
\text { Financial and insurance activities (K) } \\
\text { Real estate, prof. and admin. activities } \\
\text { (L- N) } \\
\text { Public admin., defence, social security } \\
\text { (O) } \\
\text { Education (P) } \\
\text { Human health and social work } \\
\text { activities (Q) } \\
\text { Arts, other services...(R - U) }\end{array}$ & $\begin{array}{l}0.075 \\
0.309 \\
0.161 \\
0.094 \\
0.125 \\
0.014 \\
0.028 \\
0.006 \\
0.057 \\
0.065 \\
0.037 \\
0.009 \\
0.019\end{array}$ & $\begin{array}{l}0.045 \\
0.020 \\
0.021 \\
0.054 \\
0.094 \\
0.183 \\
0.112 \\
0.045 \\
\end{array}$ & $\begin{array}{l}0.051 \\
0.270 \\
0.138 \\
0.148 \\
0.136 \\
0.011 \\
0.015 \\
0.007 \\
0.077\end{array}$ & $\begin{array}{l}0.019 \\
0.177 \\
0.010 \\
0.160 \\
0.036\end{array}$ & $\begin{array}{l}0.070 \\
0.230 \\
0.134 \\
0.113 \\
0.164 \\
0.014 \\
0.037 \\
0.011 \\
0.074 \\
0.077 \\
0.034 \\
0.019 \\
0.023\end{array}$ & $\begin{array}{l}0.026 \\
0.117 \\
0.009 \\
0.177 \\
0.054 \\
\\
0.044 \\
0.017 \\
0.028 \\
0.071 \\
0.106 \\
0.193 \\
0.106 \\
0.052 \\
\end{array}$ \\
\hline $\begin{array}{l}\text { Firm size }^{1)} \\
0-10 \text { employees } \\
11+\text { employees }\end{array}$ & $\begin{array}{l}0.167 \\
0.833 \\
\end{array}$ & $\begin{array}{l}0.184 \\
0.816 \\
\end{array}$ & $\begin{array}{l}0.096 \\
0.904 \\
\end{array}$ & $\begin{array}{l}0.102 \\
0.898 \\
\end{array}$ & $\begin{array}{l}0.169 \\
0.831 \\
\end{array}$ & $\begin{array}{l}0.201 \\
0.799 \\
\end{array}$ \\
\hline Contract (limited duration) ${ }^{1)}$ & 0.004 & 0.006 & 0.017 & 0.010 & 0.008 & 0.002 \\
\hline Managerial position $^{1)}$ & 0.277 & 0.258 & 0.162 & 0.129 & 0.074 & 0.083 \\
\hline $\mathrm{N}$ & 2179 & 2154 & 1488 & 1612 & 1833 & 2013 \\
\hline
\end{tabular}

Note: ${ }^{1)}$ Share in individual groups (mean of dummy variables), standard deviation in parentheses.

Source: EU-SILC data 2016; authors' computations. 
Fig u r e 1

Raw Gender Pay Gap in Baltic Countries in 2016

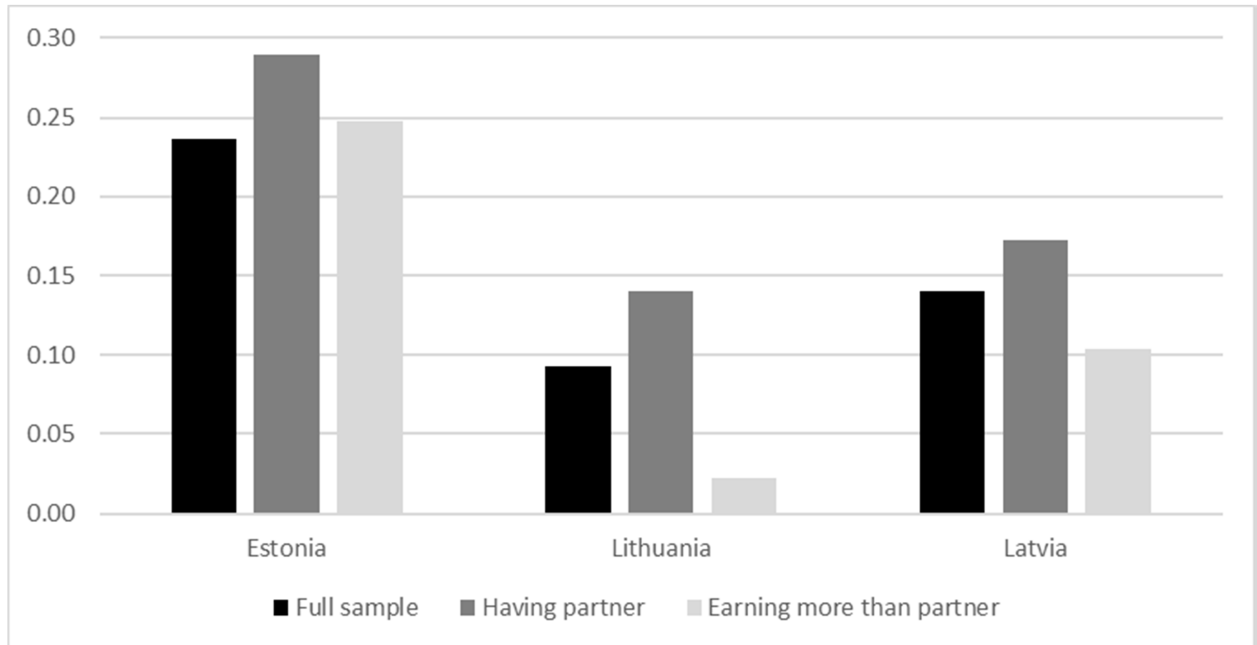

Note: Raw gender pay is calculated as the differences in logarithm of average female and male gross hourly wage.

Source: EU-SILC data 2016; authors' computation.

We can see that the wage difference between men and women earning more than their partner was smaller as compared with group of employees with partner in all Baltic countries. This decline could be at least partly attributed to intrahousehold specialization. Employees earning more than their partner spend similar efforts and their performance should be more similar. Their wage should be therefore comparable. However, above data is very raw and rather indicative. The decline of wage disparity or its part could be also due to better average characteristics of women as compared with men in this sample. To adjust the raw gender pay gap for differences that can be explained by variation in personal and firm characteristics of men and women, we will utilize unexplained gender pay gap.

There are several methods to estimate the unexplained part of gender pay gap. The includes Oaxaca-Blinder decomposition and its modification or an estimate of wage function using linear regression model. To estimate the potential wage discrimination against women we employ Oaxaca-Blinder decomposition. This method allows us to divide the gender pay gap into the part which can be explained by different characteristics of men and women and the part that remains unexplained and is often addressed to wage discrimination against women (Oaxaca, 1973; Blinder, 1973).

The Oaxaca-Blinder decomposition is given by

$$
\ln \left(\bar{W}_{m}\right)-\ln \left(\bar{W}_{f}\right)=\left(\bar{X}_{m}-\bar{X}_{f}\right) \cdot \beta^{*}+\left(\hat{\beta}_{m}-\beta^{*}\right) \cdot \bar{X}_{m}+\left(\beta^{*}-\hat{\beta}_{f}\right) \cdot \bar{X}_{f}
$$


where $\bar{W}_{m}$ and $\bar{W}_{f}$ are the values of average hourly earnings for men of women, $\bar{X}_{m}$ and $\bar{X}_{f}$ are vectors of average characteristics for both genders, $\hat{\beta}_{m}$ and $\hat{\beta}_{f}$ are the vectors of the wage functions coefficients, $\beta^{*}$ is the vector of wage functions coefficients in the absence of discrimination (equilibrium wage). The term of $\ln \left(\bar{W}_{m}\right)-\ln \left(\bar{W}_{f}\right)$ expresses the raw gender pay gap, which is defined as the difference in logarithmic mean wages of men and women. The term $\left(\bar{X}_{m}-\bar{X}_{f}\right) . \beta^{*}$ represents the part of the gender pay gap which is explained by different characteristics of men and women in the sample. This part of pay differences is known as the endowment effect. Finally, the term of $\left(\hat{\beta}_{m}-\beta^{*}\right) \cdot \bar{X}_{m}+\left(\beta^{*}-\hat{\beta}_{f}\right) \cdot \bar{X}_{f}$ is the unexplained part of the gender pay gap where the first part is the male advantage and the other the female disadvantage. This is known as the remuneration effect or the effect of discrimination.

Decomposition is based on an estimate of the wage functions for men and women. The wage equations for men and women are defined as follows

$$
\begin{aligned}
& \ln \left(W_{i}\right)_{m}=\beta_{m} \cdot\left(X_{i}^{\prime}\right)_{m}+\left(u_{i}\right)_{m}, \quad E\left(u_{i}\right)_{m}=0 \\
& \ln \left(W_{i}\right)_{f}=\beta_{f} \cdot\left(X_{i}^{\prime}\right)_{f}+\left(u_{i}\right)_{f}, E\left(u_{i}\right)_{f}=0
\end{aligned}
$$

where

$\left(W_{i}\right)_{m}$ and $\left(W_{i}\right)_{f} \quad$ - the gross hourly earnings of $i$-th man and $i$-th woman,

$\left(X^{\prime}{ }_{i}\right)_{m}$ and $\left(X^{\prime}{ }_{i}\right)_{f}$ - the vectors of the chosen characteristics of the $i$-th man and $i$-th woman,

$\beta_{m}$ and $\beta_{f} \quad-$ the vectors of coefficients of male and female wage function,

$\left(u_{i}\right)_{m}$ and $\left(u_{i}\right)_{f} \quad$ - the errors.

The other step in decomposition is setting the non-discriminatory wage structure. In empirical studies, working with the Oaxaca-Blinder decomposition, we can find various concepts of the equilibrium wage $\left(\beta^{*}\right)$. We set the nondiscriminatory wage structure using the pooled sample as proposed by Neumark (1988) and Oaxaca and Ransom (1994). We estimate the coefficients of the wage function for whole sample as follows

$$
\ln \left(W_{i}\right)=\beta^{*} \cdot X_{i}^{\prime}+u_{i}
$$

where

$W_{i}$ - the gross hourly earnings of $i$-th employee,

$X^{\prime}{ }_{i}-$ the vectors of the chosen characteristics of the $i$-th employee,

$\beta^{*}-$ the vectors of wage function coefficients,

$u_{i}$ - the error. 
As a response variable to the wage functions (equation 2, 3 and 4), we use the logarithm of the gross hourly earnings. It is calculated as the employee's cash, near cash and non-cash incomes per year divided by the number of hours usually worked per year (including overtime). ${ }^{1}$ We use selected personal characteristics (age, age squared, education, sickness and partnership) and company characteristics (occupation, sector, company size, contract and managerial position) as explanatory variables. Age and education are the proxies for human capital, age indicates the age in years, and education is a set of dummy variables, which denotes the highest level of education that a person has successfully completed using the ISCED 2011 which includes 9 categories for educational attainment. Sickness is a dummy variable which denotes whether the employee was temporarily unable to work due to a sickness during the income reference period. Partnership is a dummy variable which indicates whether the person has a partner living in the same household. Occupation is a set of dummy variables which indicates the person's occupation according to ISCO-08 (two digits). Sector is a set of dummy variables which denotes the branch in accordance with NACE Rev. 2 (13 categories: A, B - E, F, G, H, I, J, K, L - N, O, P, Q, R - U). Company size is a dummy variable showing the number of persons in their main job. There are two categories: the size of 1 and 10 employees, and the size of more than 11 employees. Contract is a dummy variable which denotes the type of contract whether permanent or temporary. Managerial position is a dummy variable reflecting a supervisory function, where the supervisory function means formal responsibility for supervising a group of other employees. We use the Ordinary Least Square (OLS) to estimate the coefficients of male, female and pooled wage functions (equation 2, 3 and 4). Then, we calculate the unexplained part of the gender pay gap using equation 1 .

To compare the gender wage differences among Baltic countries, we estimate the unexplained gender pay gap for each country.

To minimalize potential bias from too different samples of women and men, we use matching as a pre-processing procedure as proposed by Ho et al. (2007). Matching procedure unable us to get more homogenous sample of employees to compare the wage difference for comparable women and men. Many matching procedures exist. When exact matching is the simple and the most accurate in terms of sample homogeneity. This is based on the fact that, in our case, it excludes males and females who do not have exactly the same observable characteristics as the opposite sex. Because of exact matching using wide range of observed characteristics causes a big reduction of samples, we use coarsened

\footnotetext{
${ }^{1}$ A detailed description of cash and near cash and non-cash incomes and their items is available in Eurostat (2017).
} 
exact matching (CEM), which performs exact matching on coarsened data. It coarsens variables into groups and goes on to exclude untreated units, whose coarsened characteristics do not match with any treated units and vice versa. Finally, it returns uncoarsened data from observations that were matched (Blackwell et al., 2009). We matched the samples using key personal and firm observed characteristics: age, education, country, occupation and sector. Variable age was coarsened into ten conventional groups $(<20,20-24,25-29,30-34$, $35-39,40-44,45-50,50-54,55-60$ and $60+)$, education into three groups (ISCED 2011 categories $0-2,3-4,5-8$ ) and occupation into ten groups according one digit ISCO-08. On remaining variables (sector and country) exact matching was applied directly. Then we estimate the unexplained part of gender pay gap using Oaxaca-Blinder decomposition.

\section{Results}

We apply equation 1 and by using Oaxaca-Blinder decomposition we estimate the unexplained part of gender pay gap for Baltic counties (Lithuania, Latvia and Estonia). The results are shown in the Table 2. The main aim of the paper is to calculate the possibly discriminatory part of gender pay gap for the subsample of employees which earns more than their partners. However, we also estimate this for the full sample of employees and for the subsample of men and women having partners for the purpose of comparison.

The results show that the unexplained part of the gender pay gap differs significantly among Baltic countries. Using full sample of employees, the unexplained gender pay gap is the largest in Estonia where it amounts 25.8 percent and it is significantly lower in Lithuania (12.8 percent) and Latvia (14.6 percent).

The results also show that the unexplained gender difference in wages is higher for individuals who have a partner. The unexplained gender pay gap reaches more than 30 percent in Estonia, 15 percent in Lithuania and 17.5 percent in Latvia. The reason for this may be intra-household specialization, where women traditionally take care of family and children when this role is attributed to them by society. This brings two aspects. First of all, women can actually be less powerful than men, so they could prefer the family to career and work performance, and their work performance and load could be lower compared to men. Because of the care of children, they could also more often absent from work. Hence, part of the unexplained wage difference could be explained by the unobservable differences in performance between men and women (unobservable due to difficult measurement and lack of data). Secondly, from the employer's point of view, women having partner and children can be viewed a priory as not 
being able to give the same performance as men due to their dominant role in caring family. Due this fact, female wage is lower than male having the same performance characteristics. This can lead to an increase in discriminatory part of pay gap.

Table 2

Oaxaca-Blinder Decomposition: Sample without Matching

\begin{tabular}{|c|c|c|c|c|c|c|}
\hline & \multicolumn{2}{|c|}{ Full sample } & \multicolumn{2}{|c|}{ Having partner } & \multicolumn{2}{|c|}{ Earning more than partner } \\
\hline & raw $G P G$ & unexplained & raw $G P G$ & unexplained & raw $G P G$ & unexplained \\
\hline Estonia (EE) & $\begin{array}{l}0.236 \text { *** } \\
(0.018)\end{array}$ & $\begin{array}{l}0.258^{* * * *} \\
(0.019)\end{array}$ & $\begin{array}{l}0.290 * * * \\
(0.020)\end{array}$ & $\begin{array}{l}0.306 * * * \\
(0.022)\end{array}$ & $\begin{array}{l}0.248 * * * \\
(0.031)\end{array}$ & $\begin{array}{l}0.242 * * * \\
(0.030)\end{array}$ \\
\hline $\mathrm{N}$ & \multicolumn{2}{|l|}{4333} & \multicolumn{2}{|l|}{3246} & \multicolumn{2}{|l|}{1260} \\
\hline Lithuania (LT) & $\begin{array}{l}0.093 * * * \\
(0.019)\end{array}$ & $\begin{array}{l}0.128 * * * \\
(0.022)\end{array}$ & $\begin{array}{l}0.140 * * * \\
(0.023)\end{array}$ & $\begin{array}{l}0.149 \text { **** } \\
(0.027)\end{array}$ & $\begin{array}{c}0.022 \\
(0.035)\end{array}$ & $\begin{array}{l}0.140 * * * \\
(0.036)\end{array}$ \\
\hline $\mathrm{N}$ & \multicolumn{2}{|l|}{3100} & \multicolumn{2}{|l|}{2204} & \multicolumn{2}{|l|}{852} \\
\hline Latvia (LV) & $\begin{array}{l}0.140 * * * \\
(0.017)\end{array}$ & $\begin{array}{l}0.146^{* * * *} \\
(0.018)\end{array}$ & $\begin{array}{l}0.173^{* * *} \\
(0.022)\end{array}$ & $\begin{array}{l}0.175 * * * \\
(0.023)\end{array}$ & $\begin{array}{l}0.104 * * * \\
(0.036)\end{array}$ & $\begin{array}{l}0.152 * * * \\
(0.035)\end{array}$ \\
\hline $\mathrm{N}$ & \multicolumn{2}{|l|}{3846} & \multicolumn{2}{|l|}{2381} & \multicolumn{2}{|l|}{936} \\
\hline
\end{tabular}

Note: Standard errors in parentheses, $* * * \mathrm{p}<0.01, * * \mathrm{p}<0.05, * \mathrm{p}<0.1$.

Source: Authors' computations.

However, the intra-household specialization if it is linked to actual differences in productivity of partners can be legitimate reason for difference in wage. Hence, a lower female wage can be partly attributed to the intra-household specialization implying the dominant role of women in caring for the household and family and men as breadwinner. To minimize this effect at least partly, we estimate the unexplained gender pay gap for the subsample of men and women earning more than their partners expecting that the household and family care lies on a partner who earns less. The results are shown in last column of Table 2. Using this subsample, the unexplained part of gender pay gap is about 24 percent in Estonia, 14 percent in Lithuania and 15 percent in Latvia. Compared to full sample, the discriminatory part of gender wage differences declines in the Estonia. On the other hand, it increases in Lithuania and slightly also in Latvia. The reason for the growth of unexplained gender pay gap may be difference in composition of samples for individual countries and the fact that wage differences between men and women without partners are significantly lower as we discussed above.

When we compare the unexplained gender pay gap estimated for subsample of employees having partners and subsample of employees earning more than their partners, we can conclude that the unexplained gender pay gap is lower in the second case in all Baltic countries. We can also observe that the differences between individual countries decrease using the subsample of employees earning more than partners. 
However, the estimated wage differences between men and women could be biased to some extent. One of the reasons could be differences in composition of sample of men and women. To minimalize potential bias from too different samples of women and men, we use matching as a pre-processing procedure as proposed by Ho et al. (2007). To get more comparable sample of men and women in each country, we apply coarsened exact matching. We match the employees using key personal and company observed characteristics: age, education, occupation (1digit) and sector. The sample after matching procedure is referred to as CEM sample. After matching we get narrowed but more homogenous sample of men and women in each country. Then we estimate the unexplained gender pay gap in each Baltic countries. The results are presented in the Table 3.

After matching, the estimated wage difference is slightly lower for all subsamples. Relatively significant differences in the unexplained pay gap remain between Estonia and the rest Baltic countries. The estimated unexplained wage difference is 25 percent in Estonia. In Lithuania and Latvia, it is lower by almost half and reaches 13 percent in Lithuania and 14 percent in Latvia. Also, the estimated unexplained wage difference adjusted for the effect of intra-household specialization has fallen in all countries.

T a ble 3

Oaxaca-Blinder Decomposition: CEM Sample

\begin{tabular}{|c|c|c|c|c|c|c|}
\hline & \multicolumn{2}{|c|}{ Full sample } & \multicolumn{2}{|c|}{ Having partner } & \multicolumn{2}{|c|}{ Earning more than partner } \\
\hline & raw $G P G$ & unexplained & raw $G P G$ & unexplained & raw $G P G$ & unexplained \\
\hline Estonia (EE) & $\begin{array}{l}0.246^{* * * *} \\
(0.020)\end{array}$ & $\begin{array}{l}0.251 * * * \\
(0.020)\end{array}$ & $\begin{array}{l}0.294 * * * \\
(0.024)\end{array}$ & $\begin{array}{l}0.295 * * * \\
(0.023)\end{array}$ & $\begin{array}{l}0.232 \text { *** } \\
(0.039)\end{array}$ & $\begin{array}{l}0.214 * * * \\
(0.034)\end{array}$ \\
\hline $\mathrm{N}$ & \multicolumn{2}{|l|}{3360} & \multicolumn{2}{|l|}{2384} & \multicolumn{2}{|l|}{732} \\
\hline Lithuania (LT) & $\begin{array}{l}0.112 * * * \\
(0.022)\end{array}$ & $\begin{array}{l}0.126^{* * * *} \\
(0.023)\end{array}$ & $\begin{array}{l}0.144 * * * \\
(0.026)\end{array}$ & $\begin{array}{l}0.147 * * * \\
(0.028)\end{array}$ & $\begin{array}{c}0.041 \\
(0.043)\end{array}$ & $\begin{array}{l}0.109 * * * \\
(0.039)\end{array}$ \\
\hline $\mathrm{N}$ & \multicolumn{2}{|l|}{2566} & \multicolumn{2}{|l|}{1758} & \multicolumn{2}{|l|}{544} \\
\hline Latvia (LV) & $\begin{array}{l}0.154 * * * \\
(0.020)\end{array}$ & $\begin{array}{l}0.142 * * * \\
(0.019)\end{array}$ & $\begin{array}{l}0.185^{* * *} * \\
(0.025)\end{array}$ & $\begin{array}{l}0.162 * * * \\
(0.025)\end{array}$ & $\begin{array}{l}0.104 * * \\
(0.043)\end{array}$ & $\begin{array}{l}0.116^{* * * *} \\
(0.039)\end{array}$ \\
\hline $\mathrm{N}$ & \multicolumn{2}{|l|}{3069} & \multicolumn{2}{|l|}{1781} & \multicolumn{2}{|l|}{563} \\
\hline
\end{tabular}

Note: Standard errors in parentheses, *** $\mathrm{p}<0.01$, ** $\mathrm{p}<0.05, * \mathrm{p}<0.1$

Source: Authors' computations.

Using the subsample of employees earning more than partners, the unexplained gender pay gap is very similar in Lithuania and Latvia where it reaches about 11 percent. These conclusions are in line with the findings of Hedija (2014), which estimated an unexplained wage gap adjusted for intra-household specialization in European union countries. She identified about 10 percent wage difference between men and women to the disadvantage of women. On the other hand, unexplained gender wage differences remain very high in Estonia where it amounts more than 20 percent to disadvantage of women. The existence of 
a relatively high unexplained wage gap in Estonia is also confirmed by Anspal (2015), who identified 16.5 percent wage penalty for women using very detailed set of controlling variables. The large difference in gender pay gap in Estonia on one hand Latvia and Lithuania on other is relatively surprising. On the other hand, despite the fact that all three countries were part of the Soviet Union until the early 1990s, each of these countries has its historically conditioned national specifics. Differences can be found in existing formal and informal institutions that form behavior and actions of individuals. Differences in institutions may then be behind the differences in wage gaps. Blau and Kahn (2003) and Arulampalam, Booth and Bryan (2007) confirmed the role of wage-setting institutions in explaining the variation in the gender pay gap among countries. Hedija (2018) highlighted the role of quality of legislation in explaining the differences in unexplained part of gender pay gap. According to these authors the differences in childcare provision, wage setting institutions and in quality of legislation across EU countries may partly account for the variation in the unexplained gender pay gap. A factor that could be behind the differences in existing unexplained wage differences is the behavior of women in the labor market in these countries. In Estonia, compared to Lithuania and Latvia, there is a lower participation rate of women in the $15-39$ age group in the labor market. That is, at the age when women have children. Compared to Lithuania and Latvia, and also in the context of other EU member states, Estonia has an above-standard generous system of maternity and parental leave, which can significantly shape society's behavior (Schulze and Gergoric, 2015). Thus, women leave the labor market in Estonia for a relative long time period. They are also perceived by society as people who mainly take care of children and family. They lose their work habits, self-confidence, their working capital decreases and their return to the labor market is thus more difficult. The result is lower earnings compared to men.

Finally, we can conclude that using the subsample of employees earning more than their partners, the estimated unexplained gender pay gap decreased by 3.7 percentage points in Estonia (by 15 percent), by 1.7 percentage points in Lithuania (by 14 percent) and by 2.6 percentage points in Latvia (by 18 percent). Taking intra-household specialization into account led to a decrease in the unexplained pay gap by $14-18$ percent but not to its full explanation.

\section{Conclusion}

The existence of wage disparity between men and women is well known fact. Part of these differences can be explained by difference in personal and firm characteristics of men and women, the rest stays unexplained. One of the reasons 
for lower female wage could be intra-household specialization and dominant role of women in child- and family-care. The aim of this study was to estimate the gender pay gap in Baltic countries cleansed at least partially of the effect of intra-household specialization on productivity. To achieve this, we use a subsample of employees earning more than their partners assuming that the larger part of care for the household and children is taken up by the partner earning less.

The Baltic states are a culturally, historically and geographically close. One might therefore expect that wage differentials are very similar in these countries. Nevertheless, the empirical studies show that the raw gender pay gap and also its unexplained part varies significantly among Lithuania, Latvia and Estonia (for example Christofides, Polycarpou and Vrachimis, 2013 or Hedija, 2018). This study not only brings alternative estimates of gender pay gap to the Baltic countries, but also brings new insights into issue whether differences in intra-household specialization in individual Baltic countries can be a factor behind the observed differences.

Using the EU-SILC data and comparable sample of men and women and after adjusting the raw gender pay gap for differences in observed characteristics of men and women, we estimated the unexplained part of gender pay gap. We concluded that unexplained gender pay gap which represents the upper limit of wage discrimination against women vary among Baltic countries, taking into account the intra-household specialization. It reached approximately 11 percent in Latvia and Lithuania and was significantly higher in Estonia where it amounted about 21 percent. Taking intra-household specialization into account led to a decrease in the unexplained wage differences between men and women by $14-18$ percent but not to its full explanation.

\section{References}

ADAMCHIK, V. A. - BEDI, A. S. (2003): Gender Pay Differentials during the Transition in Poland. The Economics of Transition, 11, No. 4, pp. $697-726$.

ANSPAL, S. (2015): Gender Wage Gap in Estonia: A Non-parametric Decomposition. Baltic Journal of Economics, 15, No. 1, pp. $1-16$.

ARULAMPALAM, W. - BOOTH, A. - BRYAN, M. (2007): Is there a Glass Ceiling over Europe? Exploring the Gender Pay Gap across the Wage Distribution. Industrial \& Labor Relations Review, 62, No. 2, pp. $163-186$.

BALCAR, J. - GOTTVALD, J. (2016): Wage Determinants and Economic Crisis 2008 - 2014: Evidence from the Czech Republic. Ekonomický časopis/Journal of Economics, 64, No. 1, pp. $3-21$.

BLACKWELL, M. - IACUS, S. - KING, G. - PORRO, G. (2009): CEM: Coarsened Exact Matching in Stata. The Stata Journal, 9, No. 4, pp. 524 - 546.

BLAU, F. D. - KAHN, L. M. (2003): Understanding International Differences in the gGnder Pay Gap. Journal of Labor Economics, 21, No. 1, pp. $106-144$. 
BLINDER, A. (1973): Wage Discrimination: Reduced Form and Structural Estimates. Journal of Human Resources, 8, No. 4, pp. $436-455$.

EUROSTAT (2017): Methodological Guidelines and Description of EU-SILC Target Variables. [DocSILC065 (2017 operation).] Luxembourg: European Commission.

FELFE, C. (2012): The Motherhood Wage Gap: What about Job Amenities? Labour Economics, 19, No. 1, pp. $59-67$.

FILIPOVÁ, L. - PYTLÍKOVÁ, M. - BALCAR, J. - GOTTVALD, J. (2012): Reinvestigating the Determinants of Gender Wage Gap: Evidence from Survey. In: PYTLIKOVÁ, M. et al. (ed.): Gender Wage Gap and Discrimination in the Czech Republic. Ostrava: VŠB-TU Ostrava, pp. $57-83$.

GORAUS, K. - TYROWICZ, J. (2014): Gender Wage Gap in Poland - Can It Be Explained by Differences in Observable Characteristics? Ekonomia Journal, 36, No. 1, pp. 125 - 148.

HEDIJA, V. - MUSIL, P. (2010): Genderová mzdová mezera. [Working Paper CVKSČE, No. 12/2010.] Brno: CVKSČE MU.

HEDIJA, V. (2014): Do Women Really Face Wage Discrimination on the Labor Market? An Analysis Using Intra-household Specialization. Acta Universitatis Agriculturae et Silviculturae Mendelianae Brunensis, 62, No. 6, pp. 1279 - 1286.

HEDIJA, V. (2018): Is the Rule of Law Significant for the Explanation of Differences in the Gender Pay Gap? Prague Economic Papers, 27, No. 6, pp. 704 - 722.

HO, D. E. - IMAI, K. - KING, G. - STUART, E. A. (2007): Matching as Nonparametric Preprocessing for Reducing Model Dependence in Parametric Causal Inference. Political Analysis, 15, No. 2007, pp. $199-236$.

CHRISTOFIDES, L. N. - POLYCARPOU, A. - VRACHIMIS, K. (2013): Gender Wage Gaps, 'Sticky Floors' and 'Glass Ceilings' in Europe. Labour Economics, 21, No. C, pp. 86 - 102.

MYSÍKOVÁ, M. (2012): Gender Wage Gap in the Czech Republic and Central European Countries. Prague Economic Papers, 21, No. 3, pp. 328 - 346.

NEUMARK, D. (1988): Employers' Discriminatory Behavior and the Estimation of Wage Discrimination. The Journal of Human Resources, 13, No. 3, pp. 279 - 295.

OAXACA, R. L. - RANSOM, M. R. (1994): On Discrimination and the Decomposition of Wage Differentials. Journal of Econometrics, 61, No. 1, pp. 5 - 21.

OAXACA, R. L. (1973): Male-female Wage Differentials in Urban Labour Markets. International Economic Review, 14, No. 3, pp. 693 - 709.

PAILHE, A. (2000): Gender Discrimination in Central Europe during the Systemic Transition. Economics of Transition, 8, No. 2, pp. $505-535$.

RÕÕM, T. - KALLASTE, E. (2004): Men and Women in the Estonian Labor Market: An Assessment of the Gender Wage Gap. [PRAXIS Policy Analysis, No. 8/2004.] Tallinn: PRAXIS Center for Policy Studies.

SCHULZE, E. - GERGORIC, M. (2015): Maternity, Paternity and Parental Leave: Data Related to Duration and Compensation Ratesin the European Union - Study for the FEMM Committee, Brussels. Brussels: European Parlament.

VILERTS, K. - KRASNOPJOROVS, O. (2016): What Causes the Gender Wage Gap in Latvia? In: Proceedings of the New Challenges of Economic and Business Development - 2016 Conference. Riga: University of Latvia, pp. 917 - 927.

WALDFOGEL, J. (1998). Understanding the 'Family Gap' in Pay for Women with Children. Journal of Economic Perspectives, 12, No. 1, pp. 137 - 156.

WEICHSELBAUMER, D. - WINTER-EBMER, R. (2005): A Meta-Analysis of the International Gender Wage Gap. Journal of Economic Surveys, 19, No. 3, pp. 479 - 511. 